\title{
COVID pandemic and online teaching in medical practice in developing country
}

Maharjan DK' ${ }^{1 D} \otimes$, Regmee $\mathrm{S}^{2}$

'Dhiresh Kumar Maharjan, Assistant Professor; ${ }^{2}$ Sujan Regmee, Senior resident, Department of Surgery, Kathmandu Medical College Teaching Hospital, Kathmandu, Nepal.

Covid pandemic has been one of the worst $\checkmark$ pandemic faced my mankind in this century after the Spanish flu in 1918. The pandemic is far from over and the incidence of the disease is still on the rise. Although vaccine has been under the process of manufacturing, vaccines being available commercially is a far reality. Looking at geopolitical scenario, the western countries have been much hardly affected than developing countries which could probably due to low socioeconomic status in the east leading to lower rate of testing and identification of cases. The focus during the pandemic has been on containing the virus. The measures undertaken by the governments to limit the spread of the virus have disrupted health professions' education. Millions of students worldwide have been affected by the pandemic. Lockdown measures implemented by the governments have resulted in the closure of many educational institutes worldwide. ${ }^{1,2}$ As the disease is highly contagious and the best known method of prevention is maintaining a physical distance between individuals, the pandemic has forced students to remain away from their schools and colleges.

Access this article online

Website: www.jkmc.com.np

DOI: https://doi.org/10.3126/jkmc.v9i3.36418

HOW TO CITE

Maharjan DK, Regmee S. COVID pandemic and online teaching in medical practice in developing country. J Kathmandu Med Coll. 2020;9(3):119-21.

Address for correspondence

Dr. Dhiresh Kumar Maharjan

Assistant Professor, Department of Surgery

Kathmandu Medical College Teaching Hospital

Kathmandu, Nepal

E-mail: maharjandhiresh@gmail.com

Copyright @ 2020 Journal of Kathmandu Medical College (JKMC)

ISSN: 2019-1785 (Print), 2091-1793 (Online)

(7) (5) This work is licensed under a Creative Commons cc) Attribution-Non Commercial 4.0 International License.

\section{IMPACT OF THE PROBLEM}

As the education institutes were closed and students were forced to stay home because of the "Physical distancing" measures implemented by the government, the education of both the undergraduate and postgraduate medical students were affected. Both theoretical and practical classes are a major part of medical education. Theoretical classes were affected as large gatherings were avoided. Though the practical classes are usually conducted in small groups, but it involves interaction with patients. As the patient that the student is interviewing or examining can be infected with the disease it increased the chance of the student being exposed to the virus.

These students could be the potential carriers of the disease, as spread of the virus was seen from asymptomatic patients as well. This led to the closure of the educational institutes worldwide both for the safety of the students and their families.,

Apart from the education, assessment of the students were also largely affected. The theoretical exams were taken with the use of the online platforms. Practical examination were largely affected as large part of the medical practical exams are conducted in front of the patients, which again posed a risk for both the examiners and examinees of being exposed to the virus.

Most of the educational institutes shifted to online platforms for their academic activities. Zoom, Google Meet, Google Classroom, Microsoft Teams, D2L are only a few to name such platforms. ${ }^{5,6}$ Such online platforms were used in our country as well. The online platforms combines the visual, textual and auditory formats of information which helps to do a PowerPoint presentation, allows video playback and text chats to discuss and raise queries. So the online platform of education was found to be effective in so many ways. It greatly facilitated the problem based learning and small group discussion sessions. But in developing countries like Nepal, with limited resources, engaging the students 
has been a major challenge. Lack of internet access, lack of continuous energy supply, lack of electronic devices hindered smooth learning for our students. More over a sense of anxiety and a lack of continuous attentiveness during online learning also affected our students. Besides, medical educationist were facing twice the trouble with working at hospitals in the isolation wards along with taking care of student's academic activities. There were instances when senior medical educationist had to be trained and retained about online platforms like ZOOM, Goggle classroom etc. The students greatly lacked in hands on training and bedside teaching, this led to an increased anxiety level among the students as they grossly lacked in the practical skills which they were expected to attain.

The medical students today are the doctors of tomorrow. Medical students need to use all their senses to learn medicine, which is usually by seeing or doing. Some of the medical students have felt that they have missed a chance to learn about the practical response in a pandemic.? The online platform of learning was simply unable to fill this void. The students could not see or participate directly in the fight that the front line workers were fighting while tackling this pandemic. This was in contrary to other natural disaster like the earthquake where all interested students voluntarily and whole heartedly participated in patient care.

\section{RESPONSE TO THE SITUATION}

As quoted "Problem is the best time for opportunity", this pandemic has taught us that challenges can be overcome with collective effort. Many online tutorials to medical educationist were conducted before applying to the students. Various zoom meetings and online classes were held to train and orient the teachers. After some initial hiccups online theory and even practical classes were taken. The major challenge however was the assessment of the students. The online platforms were fairly adequate to take lectures and practical classes but online examinations were not as effective. To ensure exam integrity various proctoring method were used worldwide. ${ }^{8}$ It was done by either biometric based proctoring or software provided by companies like ProctorU.

In our setting the lectures were largely delivered using ZOOM meeting or other online platforms. Theoretical exams were taken using similar platforms were the activities of the students were monitored by few invigilators, while the students wrote the exam, with the help of online webcams. The students after completing the exam scanned the copy of their answer sheets and sent it to the examiners. Open book exam were also used as an alternative in many parts of the world, which abolished the chances of cheating during exams.

The department of surgery, KMCTH was faced with the challenge of conducting the university level exit exam for surgery residents. The risk to both the examiners and examinees was high as the pandemic was going on at its full strength. Conducting exams in the traditional manner seemed out of question. To add to the challenge two of the examinees had tested positive to the virus with mild symptoms. The safety of the patients were also jeopardized as the examinee doctors who are supposed to interview and examine them had tested positive themselves. Providing personal protective equipment to all involved was out of question as the supplies were limited. So the exam was conducted virtually were the students were not exposed to the patients. PowerPoint slides of virtual case scenarios were made and shown to the students and relevant questions were asked. Exam was conducted in big hall and a healthy physical distance was maintained. Post exam feedback was taken from the students, were most of the students liked the format of the exam on the background of the ongoing pandemic. The students felt safe and their anxiety levels were low. Moreover the virtual scenario enabled us to include a wide variety of cases for the exams even at the time of such crisis, as the number of elective surgery cases were limited in the inpatient department.

\section{CONCLUSION}

Practices worldwide have shown advantages and disadvantages of online platform for medical education. Less attendance, lack of face to face interaction are few challenges of such platforms. However as necessity is the mother of creation the pandemic has paved ways for creative teaching and learning activities. When traditional and time tested ways of teaching was not possible the pandemic has paved ways for newer ways of delivering education. This experience will definitely help us improve the overall fate of medical education if we could mix the conventional ways of the past to the innovations of the present.

\section{Conflict of interest: None}




\section{REFERENCES}

1. COVID-19Educational Disruption and Response. UNESCO. 4 March 2020. Available from:https:// en.unesco.org/ covid19/educationresponse

2. Reimers FM. Schleicher A. A framework to guide an education response to the COVID-19 Pandemic of 2020. OECD; 2020. [Full Text]

3. Sandhu P, de Wolf M. The impact of COVID-19 on the undergraduate medical curriculum. Medical Education Online 2020; 25: 1764740. [DOI]

4. Ahmed H, Allaf M, Elghazaly H. COVID-19 and medical Education. Lancet Infect Dis. 2020;23. [DOI]
5. Micaela H. Pocono Record. Virtual learning gets mixed reviews from Pocono parents. 2020 May. [Full Text].

6. Jonathon R. Georgia awards \$21 million in digital learning grants. 2020 April. [Full Text]

7. Rose S. Medical Student Education in the Time of COVID-19. JAMA online March 31, 2020: E1E2.

8. Mitra S, Gofman MI. Towards greater integrity in online exams. Emergent research forum papers. Twenty- second Americas Conference on Information Systems, San Diego, 2016. [Full Text] 